\title{
ANTHROPOLOGY AND PALEOGENETICS
}

DOI: 10.17746/1563-0110.2020.48.2.140-148

\author{
E.V. Pererva ${ }^{1}$, N.Y. Berezina ${ }^{2}$, and M.V. Krivosheev ${ }^{3}$ \\ ${ }^{1}$ Volgograd Institute of Management - branch of RANEPA, \\ Gagarina 8, Volgograd, 400066, Russia \\ E-mail:perervafox@mail.ru \\ ${ }^{2}$ Research Institute and Museum of Anthropology, \\ Lomonosov Moscow State University, \\ Mokhovaya 11, Moscow, 125009, Russia \\ E-mail: berezina.natalia@gmail.com \\ ${ }^{3}$ Volgograd State University, \\ Universitetsky pr. 100, Volgograd, 400062, Russia \\ E-mail:tyaf@mail.ru
}

\section{Trepanations in Sauromato-Sarmatian Crania from the Lower Volga}

We describe artificial openings in crania of the Early Iron Age nomads of the Lower Volga region, owned by the Moscow State University's Research Institute and Museum of Anthropology. Such openings were found in two male specimens of the Sauromato-Sarmatian age from Bykovo (burial 4, kurgan 13) and Baranovka (burial 2, kurgan 21). Using macroscopic and X-ray examination, we attempt to identify the surgical techniques and the reasons behind the operations. The cranial vault of the Bykovo individual was trepanned by scraping and cutting, for medical purposes. The man survived the surgery, as evidenced by healing. In the case of Baranovka, the operation was performed postmortem or peri-mortem by drilling and cutting, possibly for ritual purposes. Collating these cases with others relating to the Early Iron Age nomadic (Sauromato-Sarmatian) culture of the Lower Volga region and adjacent territories and with written and archaeological sources suggests that the closest parallels come from Central Asia, and Southern and Western Siberia, where the custom of post-mortem ritual trepanations was very common. The surgical techniques practiced in the Lower Volga region were likely due to the penetration of Greek and Roman medical traditions in the mid-first millennium $B C$.

Keywords: Sauromatians, Sarmatians, nomads, Early Iron Age, Lower Volga region, trepanation.

\section{Introduction}

The cranial samples from the Sauromato-Sarmatian period kurgan cemeteries from Volgograd and Astrakhan regions curated at the Research Institute and Museum of Anthropology of the Moscow State University (MSU) were studied. Two skulls, from the Bykovo and Baranovka cemeteries, displayed openings of the cranial vault that appeared as a result of intentional manipulations with the skulls. This study sets out to describe comprehensively the lesions and to determine the possible reasons and techniques of performing these manipulations.

\section{Material and methods}

The first skull (Inv. No. KA-451) belonged to the individual from burial 4, kurgan 13 at Bykovo (Volgograd

Archaeology, Ethnology \& Anthropology of Eurasia 48/2 (2020) 140-148 E-mail: Eurasia@archaeology.nsc.ru (C) 2020 Siberian Branch of the Russian Academy of Sciences

(C) 2020 Institute of Archaeology and Ethnography of the Siberian Branch of the Russian Academy of Sciences (c) 2020 E.V. Pererva, N.Y. Berezina, M.V. Krivosheev 
Region). The kurgan was excavated in 1955 by the Volgograd expedition of the Institute for the History of Material Culture (USSR Academy of Sciences), led by K.F. Smirnov. The second skull (Inv. No. KO-286/12) belonged to the individual from burial 2 (skeleton 1), kurgan 21 at Baranovka site, located in the Chernoyarsky District, Astrakhan Region. This site was excavated in 1972 by the Volga Archaeological Expedition of the Faculty of History of the MSU, led by G.A. FedorovDavydov.

Owing to the incomplete preservation of the skeletons, the sexes and ages of the individuals were determined from cranial features, following standard protocols (Alekseev, Debets, 1964; Balabanova, 1998; Brothwell, 1981; Meindl, Lovejoy, 1985). Differential diagnostics of pathological conditions was carried out employing both macroscopic descriptive and radiological (X-ray) techniques. The X-ray examination was carried out at the MSU Research Institute and Museum of Anthropology, using a microfocus X-ray device PRDU-02, under the following protocol: tube anode voltage $50 \mathrm{kV}$; tube anode current $120 \mu \mathrm{A}$; exposition time $3 \mathrm{sec}$; magnification $\times 2$. Forensic protocols were used to determine the type of the vault wounds observed and the circumstances (perior post-mortem) in which they were caused, alongside with the methods used in traumatology of mechanical skeleton lesions (Smolyaninov, 1959; Pigolkin et al., 2002). A detailed description of the lesions was carried out following the recommendations of M.B. Mednikova (1997; 2001).

\section{Location and characteristic of the archaeological assemblages}

The Bykovo cemetery is located near the village of the same name, in the Bykovsky District, Volgograd Region, at the left bank of Volga (Fig. 1). In kurgan 13 made in the Timber Grave period, a joint burial ground of the Sauromatian age (6th to 4th centuries BC) was detected (Smirnov, 1960: 206). There was a skeleton of a young adult male buried in an extended position, on his right side, headed westwards.

The Baranovka kurgan cemetery is situated at the southern periphery of the same-name village in the Chernoyarsky District, Astrakhan Region (Fig. 1). In the southeastern sector of kurgan 21, a joint burial ground 2 was detected, which was made in a double undercut (Dvornichenko, Fedorov-Davydov, 1989: 48). The deceased (skeleton 1) was placed along the western wall of the grave, at a depth of $158 \mathrm{~cm}$, in a small deepening. The skull was found lying on the right temporal bone. The deceased was placed on a mat, in an extended supine position, headed towards south-southwest. A globe-shaped polished gray clay molded vessel



Fig. 1. Location of the kurgan cemeteries where the cases of trepanation in Sauromato-Sarmatian crania were recorded.

with a broken-off handle was found near the feet of the skeleton. A short $(45 \mathrm{~cm})$ sword with a ring pommel and straight crossguard was situated near the right femur; and a tip of a socketed two-barbed spear $(33 \mathrm{~cm})$, a whetstone $(9.5 \mathrm{~cm})$, a fragmented iron firesteel, and a firestone were along the left femur. Near the right tibia, sheep bones and a fragment of an iron knife were found. Judging by a "military" bronze fibula found near skeleton 2, the burial can be dated to the first half of the 1st century AD (Kropotov, 2010: 59-62).

\section{Description of the finds}

Skull from Bykovo. Fragments of the frontal, parietal, occipital bones and mandible were available for the study. The remains belonged to a male 30-35 years of age. A penetrating wound was detected in the central part of the right parietal bone, just above the squamosal suture, near the lower temporal line. Only the frontal and sagittal margins of the bone were present, while the occipital and squamosal margins were lost post-mortem. Owing to the absence of the squamosal margin, the lower part of the opening was not present as well.

The wound is of sub-rectangular shape, with a rounded left upper margin. The inlet on the external surface of the bone is $38.5 \mathrm{~mm}$ in the sagittal plane, and $32.5 \mathrm{~mm}$ in the transverse plane; the outlet at the inner bone surface is $22 \times 18 \mathrm{~mm}$ (Fig. 2, $a, b$ ). The external 



C

Fig. 2. Right parietal bone of a 30-35 year-old male from burial 4 , kurgan 13 at Bykovo.

$a$ - trepanation opening; $b$ - trepanation area, view from the inside; $c$ $\mathrm{X}$-ray image of the trepanation area.

margins and walls of the lesion are smooth, straight, and slightly rounded. The diploe of the parietal bone is not traceable. The walls of the wound, up to $7 \mathrm{~mm}$ wide, are covered by newly formed periosteum, and inclined inside the cranial cavity. No manifestation of an inflammation was detected at the inner surface of the bone. The margins are straight, and well-formed. The wall of the frontal margin of the lesion is almost vertical, while the walls of the sagittal and occipital margins are oblique. Judging by its present appearance, the opening was initially of a rhomboid shape, with rounded angles, and its long axis was oriented along the sagittal suture. Two fissures, pointing towards the sagittal suture, are found on the upper margin of the lesion, while one more fissure begins from the upper right angle towards the frontal bone. These fissures are most likely of postmortem origin.

The surgery was carried out pre-mortem, and the signs of healing on the walls and margins of the wound suggest that the individual survived the operation for a long time. The trepanation was likely carried out by a right-handed person, who was removing bone tissue by combining different surgical techniques: scraping and cutting by a sharp tool in a top-down direction. As a result, the sagittal and occipital margins of the lesion display a more shallow and rounded shape.

Skull from Baranovka. The skull belonged to a male of 25-35 years of age. The facial skeleton and most of the cranial base of the specimen are missing. A penetrating wound of irregular sub-trapezoid form was detected in the temporal squama. The long axis of the lesion was oriented sagittally, the base of the "trapezium" was located closer to the parietal margin, its apex to the sphenoidal margin of the bone (Fig. 3,a). The length of the opening is $29.5 \mathrm{~mm}$; the maximum width is $22 \mathrm{~mm}$. The thickness of the bone at the margins of the lesion is $3 \mathrm{~mm}$. Both the external and internal margins of the wound are sharp.

The upper margin of the perforation is arch-shaped, and its walls are inclined internally. The walls display manifestations of the drilling of eight holes of various diameters, separated by bone septa up to $2 \mathrm{~mm}$ thick (Fig. 3, b). The first hole is located $17 \mathrm{~mm}$ from the upper margin of the squama, and $24 \mathrm{~mm}$ from the parietal margin of the temporal bone. It is semicircular, penetrating, with walls inclined inside the cranial cavity. Its external diameter is $4 \mathrm{~mm}$, internal $2 \mathrm{~mm}$. The second hole is $1.5 \mathrm{~mm}$ from the first one. Its external diameter is $2 \mathrm{~mm}$, internal $1.5 \mathrm{~mm}$. The third opening is situated $2 \mathrm{~mm}$ from the previous one. It is damaged, and only its right wall is present. The probable diameter of this hole was about $2.5 \mathrm{~mm}$. The fourth hole, $2 \mathrm{~mm}$ from the third one, is of a similar appearance and a diameter likely about $3 \mathrm{~mm}$. The fifth opening is a semicircular hole, $4 \mathrm{~mm}$ in diameter. From the sixth hole, only a fragment of the wall, $2 \times 2 \mathrm{~mm}$ in size, remained. The seventh perforation is located $6 \mathrm{~mm}$ from the previous one; its diameter is $4 \mathrm{~mm}$. The eighth hole is penetrating, $3 \mathrm{~mm}$ in diameter. It lies $10 \mathrm{~mm}$ from the root of the zygomatic process, very close to the seventh opening, and partially overlaps with its left wall. One more blind hole was detected, $4 \mathrm{~mm}$ from the first hole. It is situated $14 \mathrm{~mm}$ from the upper margin of the temporal squama, and at the same distance from the sphenoidal margin of the bone. 
The bottom of the pit is of rounded shape, it is $1.5 \mathrm{~mm}$ deep and $3.5 \mathrm{~mm}$ in diameter.

No manifestation of inflammatory process or newly formed bone tissue was observed on either external or internal surfaces of the temporal bone. Probably, after drilling a number of perforations in the distal part of the temporal bone, the bone walls between the holes were sawn or cut. Afterwards, a part of the bone was raised and broken. The method of trepanation can be classified as drilling and cutting (Mednikova, 2001: 31). The surgery was carried out post-mortem, possibly for ritual purposes.

\section{Results of the X-ray examination}

A circular penetrating wound and two linear fractures radiating from it were visible in X-ray images of the skull from burial 4, kurgan 13 at Bykovo. The pattern of bone-cracking and absence of periosteal reaction along the whole length of the fractures point towards a postmortem, likely taphonomic, nature of the lesions. The presence of denser undifferentiated bone tissue around the opening and a sclerotic rim at the bone-forming margin of the temporal bone suggest that the process of healing of the wound was long and successful (see Fig. 2,c).

In X-ray images of the skull from burial 2, kurgan 21 at Baranovka, a penetrating wound in the squama of the right temporal bone is observed. The walls of the lesion are irregular and consist of small rounded notches 3-4 mm in diameter. Several depressions (incomplete perforations) are seen in the outer table of the bone, along the margins of the main defect, and one more through hole $4 \mathrm{~mm}$ from it. No manifestations of periosteal reaction, boneremodeling, or sclerotic rim formation are detectable on the images, which suggests that the trepanation was carried out shortly before the death of the individual, or post-mortem (see Fig. 3, d).

\section{Discussion}

Only a few cases of cranial surgery are known for samples of the Sarmatian period from the Lower Volga. The first of these cases was described by D.G. Rokhlin, who published an X-ray image of a skull from the former Don Region (present Volgograd and Rostov regions, and the Republic of Kalmykia) and suggested a therapeutic purpose for the surgery $(1965: 174,195)$.


$b$

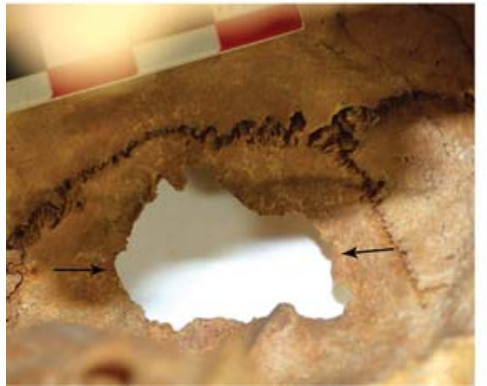

$C$



Fig. 3. Male skull with trepanation from burial 2, kurgan 21 at Baranovka. $a$ - trepanation in the left temporal bone (frontal view); $b$-trepanation opening with multiple perforations; $c$ - trepanation area, view from the inside; $d$-X-ray image of the trepanation area.

Later, forensic expert V.V. Sidorov studied a calvarium of a male dated to the Late Sarmatian period (3rd to 4th centuries AD) from kurgan 4 of the cemetery near the Glazunovskaya village, Kumylzhensky District, Volgograd Region, excavated by L.V. Gurenko in 1996. Sidorov detected a trepanation perforation of oval shape and $7 \times 6 \mathrm{~mm}$ in size in the rear part of the right parietal bone, $32 \mathrm{~mm}$ from the sagittal suture and $23 \mathrm{~mm}$ from the right lambdoid suture (Gurenko, 1996).

A case of trepanation from the Peregruznoye I cemetery was studied by E.V. Pererva. The burial is dated to the 1st AD. A perforation and a lesion from an incomplete trepanation were detected in a female skull. The surgery was carried out post-mortem, using 
a drilling technique, possibly for ritual or symbolic purposes (Pererva, 2012: 131).

Three drilling trepanations were described by V.I. Mamontov and co-authors in a skull of a female 3545 years of age from the Verbovsky I cemetery, which has been dated to the 1 st to early 2 nd centuries AD. The first opening was located in the left parietal bone, the second in the sagittal suture, and the third in the lambdoid suture (Mamontov, Obramenko, Pererva, 2018). The absence of signs of healing suggests that the trepanation was carried out peri- and/or post-mortem. The abundance of rich grave goods on the one hand, and the large number and localization of the defects on the other hand, point towards a ritual and symbolic purposes for the surgery (Ibid.: 100).

Some information regarding trepanations made by Sarmatians can be found in the studies by P.S. Rykov and S.V. Kiselev (Rykov, 1926: 105; Kiselev, 1951: 403). In a review devoted to surgical operations of the Sarmatians by D.A. Kirichenko (2016: 114), several cases are described for the Early Iron Age specimens from Hungary and Romania.

To date, only two ante-mortem therapeutic trepanations have been detected in the cranial samples of the Sauromato-Sarmatian cultures from the Lower Volga region: the one described by D.G. Rokhlin, and the second presented in this study. Similar operations made using the scraping technique and survived by the patients are known from the literature on the Early Iron Age samples from Southern Siberia and Western Kazakhstan. A case of trepanation in a female skull from the Aimyrlyg cemetery (Chaa-Kholskiy kozhuun of the Tyva Republic) was described by A. Murphy as carried out for healing purposes (2003). The perforation was made in the left part of the frontal bone. Three cases of ante-mortem trepanation were studied by T.A. Chikisheva and co-authors in specimens of the Pazyryk culture of the 4th to 3rd centuries BC, from ordinary burials of the Bike III, Kazyl-Dzhar IV and $\mathrm{V}$ cemeteries, in the Altai Mountains. According to their results, the surgeries were carried out by different persons, using the scraping technique, in two stages (Chikisheva et al., 2014; Krivoshapkin et al., 2014). An ante-mortem trepanation was described by E.P. Kitov and A.Z. Beisenov in the occipital part of the skull of a female of 35-45 years old from kurgan 25 of the Birlik cemetery (Bayanaulsky District, Pavlodar Region, the Republic of Kazakhstan). The burial represents the Tasmola archaeological culture of the 7th to 5th centuries BC (Kitov, Beisenov, 2015).

All the trepanations listed above were carried out for medical purposes using the scraping technique. The patients survived the surgeries, which is evidenced by manifestations of successful healing and boneforming processes around the wounds. According to many researchers (Ortner, Putschar, 1981; Erdal Y.S., Erdal O.D., 2011), scraping is the safest technique of therapeutic trepanation. The traditions of surgery performance by the Altai Mountains nomads were thoroughly studied by A.L. Krivoshapkin and co-authors (2014: 67). They suggested that this method of trepanation provided the highest survival rate in ancient times.

Today, little is known about the medical culture and practice of the Sauromatians, Sarmatians, and Scythians. The historian of medicine can only rely on three sources of information: written evidence from ancient authors, archaeological finds, and osteological collections from burial sites of the Eurasian steppe. The information provided by ancient authors regarding the level of medical knowledge of Early Iron Age nomads is very sketchy. For instance, Herodotus wrote about hemp baths and the use of grinds from plants as primitive soap by the Scythians (The Histories: IV, 75). Pliny the Elder mentioned the "Scythian root", which was used by the Sarmatians for curing many diseases, and snake poisons also used for healing (Natural History: XXV, 82, 83; XXIX: 69, 70). Unfortunately, this is all that the ancient historians said about this subject. Among archaeological finds, a vase from the Kul-Oba kurgan in the Crimea, dated to the 4th century $\mathrm{BC}$, is noteworthy. Drawings on the vase depict a jaw repositioning or a tooth extraction on an injured warrior, and a leg dressing of a wounded Scythian (Belova, Gulyaeva, Chernysheva, 2016: 205).

There is some anthropological evidence for a high level of medical knowledge in the Early Iron Age nomads of the Eurasian steppe. In skeletal samples of the Sarmatians and other nomads, cases of healed injuries of the skull and skeleton or successful limb-amputations are quite numerous (Pererva, Berezina, 2015; Pererva, Klepikov, 2018; Murphy, 2003). But the question of where the Scythians, Sauromatians, and Sarmatians obtained this knowledge, and the skills that made them capable of performing difficult surgeries, remains open.

To resolve this question, one needs to turn to the written sources again. Some ancient authors mentioned Scythian Asclepiads in their texts. For instance, the famous satirist Lucian of Samosata (2nd century AD) wrote about two Scythian physicians, Anacharsis and Toxaris. The latter died in Athens, and was even acknowledged as a hero and a descendant of Aesculapius (Latyshev, 1948). Herodotus and Plutarch, according to M.B. Mirsky, mentioned "professional" doctors among the Scythians, who were at the same time sorcerers and priests. The researcher supports the opinion of N.S. Dumka (1956: 58) that Scythia had its own medical schools. This notion is supported by the presence of Asclepeions in some Greco-Scythian settlements (Mirsky, 2005: 12). The Athenians considered Scythian doctors experts in their field. According to L.F. Zmeev, medical 
knowledge in Scythians and other nomadic peoples of their times was the prerogative of a semi-special class of healers (volkhvs, junior priests), while the knowledge itself was coming from the Persians, Arabs, Greeks, and Egyptians (1896: 101).

In our opinion, the medical knowledge was probably adopted by the Scythians and Sarmatians from their antique neighbors. The famous Greek doctor Hippocrates lived and worked during the Scythian-Sarmatian times. He visited Scythia and described the citizens of this country, their diseases, and the legends about Sauromatians in his book entitled "On Airs, Waters, and Places" (Hippocrates, 1936: 275-306). In his other book, "On Injuries of the Head", in Chapter 9, indications for trepanation are outlined, and also the reasons for, and techniques of, cranial surgery are thoroughly described. Recommendations for monitoring the patient after the trepanation are also provided (Ibid.: 581-601). Our opinion is basically shared by T.A. Chikisheva and co-authors, who carried out a multidisciplinary study of three cases of ante-mortem trepanations in the nomads of the Altai Mountains. According to their results, the medical knowledge and tools necessary for successful head surgeries were brought to Southern Siberia by Greek military surgeons (Chikisheva et al., 2014: 139).

As for post-mortem trepanations carried out using the drilling technique, such trepanations are described in specimens from Southern Siberia, Kazakhstan, and Mongolia. A number of researchers have studied skulls with trepanations from burials of the Tashtyk culture of the 2nd century BC to the 5th century AD. For instance, S.V. Kiselev described cases of post-mortem trepanations in the occipital part of the skull in samples of that period from the Yenisei River. He interpreted these surgeries as extraction of the brain for further mummification of the body (Kiselev, 1951: 403). According to I.I. Gokhman, the frequency of skulls with trepanations in their occipital part reaches $80-90 \%$ in some burial sites of the Tashtyk culture. Patterns of trepanations differ between sites, which points towards the existence of some specific traditions (Gokhman, 1989). A case of post-mortem trepanation was detected by S.I. Rudenko (1953: 342360 ) in the 2nd Pazyryk (5th century BC) and Shibe (2nd to 1 st centuries $\mathrm{BC}$ ) kurgans.

A male skull with trepanation from a kurgan of the Karabiye cemetery, in the Karaganda Region, Kazakhstan, dated to the 5 th to $3 \mathrm{rd}$ centuries $\mathrm{BC}$, was described by P. Boev and O. Ismagulov. They detected six openings $7.0-7.5 \mathrm{~mm}$ in diameter in the rear part of the left temporal bone and in the left part of the occipital bone. The lesions were situated obliquely from the upper medial to the lower medial sides of the braincase (Boev, Ismagulov, 1962).

A.D. Grach detected trepanations in osteological collections of the Sagly culture (5th to 3rd centuries BC) from the Sagly-Bazhi II and Mazhalyk-Khovuzu I, II cemeteries in the Tyva Republic. This researcher suggested that the surgeries were carried out for extracting the brain before embalming the bodies (Grach, 1980: 73-74).

B. Naran and D. Tumen give the description of skull 47-4 (AT-129) from the Chandman (Ulangom) cemetery of the 7th to 3rd centuries BC in Mongolia. Seven trepanation-openings were detected in the cranial vault; some of these were drilled out. The patient likely died during the operation, or the trepanation was carried out post-mortem (Naran, Tumen, 1997: 126-127). Cranial samples of the Late Tagar period from the Samokhval, Tagarsky Ostrov, and Kazyl-Kul cemeteries in Khakassia were studied by M.B. Mednikova. In these vast samples, she detected numerous cases of post-mortem trepanation performed using various techniques (Mednikova, 1997: 138). Another study of the Early Iron Age Central Asian population was carried out by a group of researchers (Kitov, Kitova, Orabay, 2016: 369-378). They described drilled trepanations in 10 skulls, wherein the number of perforations varied from 1 to 15 per skull. All defects were found in the occipital bone or in the rear part of the parietal bones.

Two finds are of particular interest in terms of their manner and technique of trepanation: a skull of a 4555 year-old male from the Karakemer cemetery in Central Kazakhstan (Kitov, Beisenov, 2015: 39) and a female skull from kurgan 1 of the Saka period locality of Kaspan Zhetysu in the Alma-Ata Region, in the Republic of Kazakhstan (Beisenov et al., 2018: 143). No manifestations of reparation or inflammation are observed in either case. These two specimens display a similarity to the trepanned male skull from the Middle Sarmatian cemetery of Baranovka in the following set of features: number and size of perforations; circular arrangement of lesions; method of trepanation (drilling); pattern of defects made at different angles to the bone surface; further combination of perforations in a single trepanation-inlet.

Most of the scholars describing post-mortem trepanations in Central Asian specimens share the view according to which such a surgery is a preliminary step before mummification or embalming of the body (Rudenko, 1953: 332; Grach, 1980: 73-74; Kiselev, 1951: 403; Kyzlasov, 1960: 101; Kitov, Kitova, Orabay, 2016: 377). This view has undoubtedly a right to exist, particularly taking into account the widespread embalming and mummification traditions in Central Asia during the Early Iron Age. But in the case of the specimens with post-mortem drilled trepanations from the Lower Volga, such an explanation cannot be accepted. No evidence of mummification or embalming of the deceased is found in Early Iron Age burials from this area. The origin of the tradition of the post-mortem manipulations 
with the braincase among the steppe nomads of the 1 st century AD in the south of the East European Plain should be probably looked for in the Early Iron Age Central Asian archaeological cultures. Their close relatedness to the Sarmatian ones is evident from archaeological data (Skripkin, 1992: 19-40; Yatsenko, 2006: 123-125). It is possible that the traditions of postmortem ritual trepanations were brought to the Lower Volga region by migrants from the east, along with the changes in burial rites and innovations in material culture, originating from Southern Siberia and Central Asia, observed in the assemblages of the 1st-2nd and 3rd-4th centuries AD in this territory.

Yet one more observation supporting this hypothesis is the fact that all burials of the Middle Sarmatian time containing skulls with perforations can be considered elite or extraordinary. In two cases (Peregruznoye and Verbovsky cemeteries) these are female burials with rich grave goods including gold jewelry, weapons, and ritual or magic items. The burial from Baranovka is quite peculiar in terms of construction, and belongs to a Middle Sarmatian warrior, as is evident from the size of the kurgan, the depth of the grave, and the presence of a short sword and a spearhead. The results of examination of the Central Asian burials containing human remains with post-mortem trepanations are outlined below. According to S.I. Rudenko, in the Pazyryk culture, trepanations were carried out only on high-status individuals, because in the ordinary graves such evidence was not recorded (1949). Similarly, A.Z. Beisenov and E.P. Kitov indicate a high social status for the individuals showing post-mortem trepanations from the Saka burials in Central Kazakhstan. These authors suggest that such burials belong to the Tasmola elite (Beisenov, Kitov, 2014: 31).

\section{Conclusions}

This study describes the only case known to date of a successful ante-mortem surgery in cranial specimens of the Sauromatian age, as well as the post-mortem trepanations carried out using the drilling and cutting technique, detected in individuals of the Middle Sarmatian period. The most likely reason for performing the cranial surgery in the young male from Bykovo was medical treatment after a trauma. The operation was carried out successfully, and the individual lived for a long time afterwards.

The braincase of the individual from Baranovka was subjected to a complex of peri- or post-mortem ritual manipulations (drilling of nine perforations, cutting of bone bridges between the perforations, crushing of the bone plate) carried out for purposes that are now very difficult to identify. The presence of incomplete perforations, their different diameters and angles, the atypical shape of one of the holes (incomplete sphere)all these features taken together suggest a lack of experience in the person who performed these operations. It is also possible that the surgery was carried out hastily or as training for medical skills. Noteworthy also is the atypical position of the trepanation defect: in the temporal area. The closest analogies to this case were found and described by M.B. Mednikova in samples from the Late Tagar cemetery of Kyzyl-Kul. The perforations were made using completely different methods and techniques, but similarly post-mortem and likely for ritual purposes (Mednikova, 2001: 212-217).

In the attempt to interpret the origin of the trepanations detected in the Sarmatian and Sauromatian samples from the Lower Volga, we have been looking for similar cases described in specimens from Central Asia, Southern and Western Siberia. There is little doubt that the tradition of post-mortem ritual trepanations in the Middle Sarmatian population from the Lower Volga region had eastern roots, since direct parallels to these are known from Central and Western Kazakhstan samples. Turning to the therapeutic surgeries of the Sauromato-Sarmatian period, it appears most likely that the relevant skills and knowledge came from the southwest and had antique origins. These skills probably penetrated into southeastern Siberia and Central Asia as a result of the contacts between ancient and barbarian (nomadic) worlds.

\section{Acknowledgement}

This study was supported by the Russian Foundation for Basic Research (Project No. 19-09-00471) and Moscow State University Grant for Leading Scientific Schools "Depository of the Living Systems" in frame of the MSU Development Program. We express our gratitude to Doctor of History, Academician of RAS, Director of the Research Institute and Museum of Anthropology of the MSU A.P. Buzhilova for scientific consultations and the possibility of working with the institute's collections and equipment purchased under the MSU Development Program.

\section{References}

\section{Alekseev V.P., Debets G.F. 1964}

Kraniometriya: Metodika antropologicheskikh issledovaniy. Moscow: Nauka.

\section{Balabanova M.A. 1998}

Metodika paleoantropologicheskikh issledovaniy: Ucheb.metod. posobiye. Volgograd: Volgogr. Gos. Univ.

Beisenov A.Z., Duisenbai D.B., Kitov E.P.,

\section{Kulkova M.A. 2018}

Issledovaniya sakskikh kurganov v urochishche Kaspan v Zhetysu. In Teoriya i praktika arkheologicheskikh issledovaniy, No. 3. Barnaul: Izd. Alt. Gos. Univ., pp. 138-162. 


\section{Beisenov A.Z., Kitov E.P. 2014}

Posmertnaya trepanatsiya cherepov v elitnykh zakhoroneniyakh sakskoy epokhi Tsentralnogo Kazakhstana. Izvestiya Altaiskogo gosudarstvennogo universiteta, No. 4/2 (84): 31-41.

Belova L.I., Gulyaeva E.S., Chernysheva I.V. 2016

Istoricheskiye svidetelstva o meditsinskoy kulture narodov Nizhnego Povolzhya s rannego zheleznogo veka do raspada Zolotoy Ordy. Izvestiya Volgogradskogo gosudarstvennogo pedagogicheskogo universiteta, No. 3: 204-209.

Boev P., Ismagulov O. 1962

Trepanirovanniy cherep iz Kazakhskoy SSR. Sovetskaya etnographiya, No. 2: 131-132.

\section{Brothwell D.R. 1981}

Digging up Bones. [Third edition]. Oxford: Oxford Univ. Press.

Chikisheva T.A., Zubova A.V., Krivoshapkin A.L.,

Kurbatov V.P., Volkov P.V., Titov A.T. 2014

Trepanation among the Early Nomads of Gorny Altai: A multidisciplinary study. Archaeology, Ethnology and Anthropology of Eurasia, No. 1: 130-141.

Dumka N.S. 1956

O skifskoy meditsine. Sovetskoye zdravookhraneniye, No. 6: 58-59.

\section{Dvornichenko V.V., Fedorov-Davydov G.A. 1989}

Raskopki kurganov v zone stroitelstva KalmytskoAstrakhanskoy i Nikolskoy risovykh orositelnykh sistem. In Sokrovishcha sarmatskikh vozhdey i drevniye goroda Povolzhya. Moscow: Nauka, pp. 14-132.

\section{Erdal Y.S., Erdal O.D. 2011}

A review of trepanations in Anatolia with new cases. International Journal of Osteoarchaeology, vol. 21: 505-534.

\section{Gokhman I.I. 1989}

Paleoantropologiya i doistoricheskaya meditsina. In Antropologiya - meditsine. Moscow: Izd. Mosk. Gos. Univ., pp. 5-16.

\section{Grach A.D. 1980}

Drevniye kochevniki v tsentre Azii. Moscow: Nauka.

Gurenko L.V. 1996

Otchet o provedenii arkheologicheskikh issledovaniy $\mathrm{v}$ Kumylzhenskom rayone Volgogradskoy oblasti (u stanitsy Glazunovskoy) v 1996 g. Arkhiv VOKM. No. 205. Iz soderzh.: Sidorov V.V. Akt sudebno-meditsinskogo issledovaniya No. 8: 21-30.

Hippocrates. 1936

Izbranniye knigi. Moscow: Gos. izd. biol. i med. lit.

Kirichenko D.A. 2016

O sluchayakh trepanatsii u sarmatskikh plemen Yevrazii.

Vestnik arkheologii, antropologii i etnografii, No. 2: 112-119.

Kiselev S.V. 1951

Drevnyaya istoriya Yuzhnoy Sibiri. Moscow: Nauka.

Kitov E.P., Beisenov A.Z. 2015

Cherepa s trepanatsiyami iz kurganov rannego zheleznogo veka Saryarki. Vestnik Moskovskogo universiteta. Ser. XXIII: Antropologiya, No. 1: 37-48.

Kitov E.P., Kitova A.O., Orabai E. 2016

Posmertniye manipulyatsii s kostyami cheloveka (danniye o mumifikatsii) u naseleniya Tsentralnoy Azii v rannem zheleznom veke. Stratum plus: Arkheologiya i kulturnaya antropologiya, No. 3: 369-380.
Krivoshapkin A.L., Chikisheva T.A., Zubova A.V., Kurbatov V.P. 2014

Trepanatsii u naseleniya Gornogo Altaya V-III veka do n.e. Voprosy neirokhirurgii, vol. 78 (3): 62-71.

Kropotov V.V. 2010

Fibuly sarmatskoy epokhi. Kiev: ADEF-Ukraina.

Kyzlasov L.R. 1960

Tashtykskaya epokha $\mathrm{v}$ istorii Khakassko-Minusinskoy kotloviny (I v. do n.e. - V v. n.e.). Moscow: Izd. Mosk. Gos. Univ.

Latyshev V.V. 1948

Izvestiya drevnikh pisateley o Skifii i Kavkaze. Vestnik drevney istorii, No. 1: 221-315.

Mamontov V.I., Obramenko I.E., Pererva E.V. 2018

Trepanatsiya cherepa iz zakhoroneniya srednesarmatskogo vremeni s territorii Volgogradskoy oblasti. Vestnik Moskovskogo universiteta. Ser.: XXIII: Antropologiya, No. 1: 86-100.

Mednikova M.B. 1997

$\mathrm{K}$ voprosu o rasprostranenii posmertnoy trepanatsii cherepov v Tsentralnoy Azii. Rossiyskaya arkheologiya, No. 4: 130-188.

Mednikova M.B. 2001

Trepanatsii u drevnikh narodov Yevrazii. Moscow: Nauch. mir.

\section{Meindl R.S., Lovejoy C.O. 1985}

Ectocranial sature closure: A revised method for the determination of skeletal age at death based on the lateralanterior sutures. American Journal of Physical Anthropology, vol. 68 : $57-66$.

\section{Mirsky M.B. 2005}

Meditsina Rossii X-XX vekov: Ocherki istorii. Moscow: ROSSPEN.

\section{Murphy E.M. 2003}

Trepanations and perforated crania from Iron Age South Siberia: An exercise in differential diagnosis. In Trepanation: History, Discovery, Theory. Lisse: Swets \& Zeitlinger Publishers, pp. 209-221.

\section{Naran B., Tumen D. 1997}

Travmaticheskiye povrezhdeniya na cherepakh Chandmanskogo mogilnika. Rossiyskaya arkheologiya, No. 4: 122-130.

\section{Ortner D.J., Putschar W.G. 1981}

Identification of pathological conditions in human skeletal remains. In Smithsonian Contributions Anthropological, No. 28. Washington: Smithsonian Institution Press, pp. 57-59.

\section{Pererva E.V. 2012}

Sluchay trepanatsii u sarmatov (po antropologicheskim materialam iz mogilnika Peregruznoye I). Vestnik Moskovskogo universiteta. Ser.: XXIII: Antropologiya, No. 2: 123-133.

\section{Pererva E.V., Berezina N.Y. 2015}

Boyeviye stolknoveniya: Nakonechniki strel v skeletakh kochevnikov (po materialam sarmatskikh pogrebeniy IV v. do n.e. - IV v. n.e.). In Paleoantropologicheskiye $i$ bioarkheologicheskiye issledovaniya: Traditsii i noviye metodiki. St. Petersburg: Lema, pp. 20-22.

Pererva E.V., Klepikov V.M. 2018

Sluchay prizhiznennoy amputatsii predplechya u voina srednesarmatskogo vremeni. KSIA, No. 253: 417-431.

Pigolkin Y.I., Barinov E.K., Bogomolov D.V., Bogomolova I.N. 2002

Sudebnaya meditsina: Ucheb. Moscow: GEOTAR-Med. 
Rokhlin D.G. 1965

Bolezni drevnikh lyudei. Moscow, Leningrad: Nauka.

Rudenko S.I. 1949

Kultura Altaya vremeni sooruzheniya pazyrykskikh kurganov. KSIIMK, iss. XXVI: 97-109.

\section{Rudenko S.I. 1953}

Kultura naseleniya Gornogo Altaya v skifskoye vremya. Moscow, Leningrad: Izd. AN SSSR.

Rykov P.S. 1926

Arkheologicheskiye raskopki i razvedki v Nizhnem Povolzhye i Uralskom kraye letom 1925 g. (predvaritelniy otchet). Izvestiya Krayeved. Inst. izucheniya Yuzhno-Volzhskoy obl. pri Saratov. Gos. Univ., vol. 1: 89-134.

Skripkin A.S. 1992

Aziatskaya Sarmatiya: Problemy khronologii, periodizatsii i etnopoliticheskoy istorii: Nauch. dokl., predstavlnniy v kachstve dis... d-ra ist. nauk. Moscow.

\section{Smirnov K.F. 1960}

Bykovskiye kurgany. In Drevnosti Nizhnego Povolzhya. Vol. II: Itogi raboty Stalingradskoy arkheologicheskoy ekspeditsii. Moscow: Izd. AN SSSR, pp. 169-268. (MIA; No. 78).

\section{Smolyaninov V.M. 1959}

Sudebnaya meditsina: Ucheb. dlya studentov med. inst. Moscow: Medgiz.

\section{Yatsenko S.A. 2006}

Kostyum drevney Yevrazii (iranoyazychniye narody). Moscow: Vost. lit.

\section{Zmeev L.F. 1896}

Chteniya po vrachebnoy istorii Rossii. St. Petersburg: [Tip. V. Demakova]. 